\title{
Host Specificity and Variations in Aggressiveness of North Carolina Isolates of Phytophthora cryptogea and P. drechsleri in Greenhouse Ornamental Plants
}

\author{
H. A. Olson and D. M. Benson, Department of Plant Pathology, North Carolina State University, Raleigh 27695
} \begin{abstract}
P. drechsleri in greenhouse ornamental plants. Plant Dis. 97:74-80.
Three isolates of Phytophthora cryptogea and three isolates of $P$. drechsleri were evaluated for host specificity and variations in aggressiveness on eight floriculture crops commonly grown in North Carolina. Plants were monitored for the development of foliar symptoms stemming from root rot caused by Phytophthora. No isolates of $P$. cryptogea or $P$. drechsleri had the same host range, though all $P$. cryptogea isolates caused foliar symptoms on gerbera daisy and annual stock, and all $P$. drechsleri isolates incited disease on osteospermum. No African marigold plants developed foliar symptoms of Phytophthora root rot. All P. cryptogea isolates caused foliar symptoms on at least three tested plant species. Isolates of $P$. drechsleri varied from
\end{abstract}

Abstract

Olson, H. A., and Benson, D. M. 2013. Host specificity and variations in aggressiveness of North Carolina isolates of Phytophthora cryptogea and

highly specific and only causing disease on a single host species to relatively nonspecific and causing foliar symptoms on the majority of host plants. This is the first report of host specificity of ornamental isolates of $P$. drechsleri, and several of the tested plants are not reported hosts of $P$. drechsleri. Differences in isolate aggressiveness were found and depended on plant species; overall, isolates of $P$. drechsleri were more aggressive than $P$. cryptogea isolates. Isolations from nonsymptomatic inoculated plants suggest that these Phytophthora spp. could be moved between growers or from growers to consumers on nonsymptomatic infected ornamentals.
Phytophthora cryptogea and $P$. drechsleri cause root and crown rot on numerous plants, including multiple greenhouse-produced ornamentals. Both species, along with $P$. nicotianae and P. tropicalis, were recovered during a 2007 to 2008 survey of floriculture crops in North Carolina greenhouses (25). P. cryptogea was isolated from blue daze (Evolvulus glomeratus), gerbera daisy (Gerbera jamesonii), dusty miller (Senecio cineraria), and verbena (Verbena $\times$ hybrida), while $P$. drechsleri was collected from gerbera daisy and fuchsia (Fuchsia $\times$ hybrida). In a 2001 to 2002 survey of North Carolina greenhouses, gerbera daisy and dusty miller were found to be hosts of $P$. drechsleri $(12,25)$. Worldwide, $P$. cryptogea has over 140 reported hosts in approximately 50 plant families (6). Of the reported hosts, approximately 40 are floriculture crops. Similarly, P. drechsleri has over 110 reported hosts in 40 plant families (7). Approximately 25 of the reported hosts are floriculture crops.

Host specificity has been reported in both species; however, little research has focused specifically on floriculture crops, and host specificity within floriculture crops has only been reported for $P$. cryptogea. In early experimental host range studies, Tompkins and Tucker (34) and Middleton et al. (24) identified isolates of $P$. cryptogea collected from ornamental hosts exhibiting host specificity. More recently, Kröber (19) proposed the name P. cryptogea $\mathrm{f}$. sp. begoniae for isolates collected from Elatior begonia (Begonia $\times$ hiemalis) that were morphologically similar to the description of $P$. cryptogea but had larger oospores, and because gerbera daisy isolates from Kröber's collection were not pathogenic to Elatior begonia.

Understanding the host ranges of isolates obtained from greenhouses could help growers manage Phytophthora root rot in orna-

\section{Corresponding author: H. A. Olson, E-mail: heather.a.olson@gmail.com}

Current address of H. A. Olson: Seminis Vegetable Seeds, Monsanto Company, Warner Robins, GA 31088.

Accepted for publication 24 July 2012.

http://dx.doi.doi/10.1094/PDIS-02-12-0170-RE

(C) 2013 The American Phytopathological Society mentals. For example, highly susceptible plant species could be targeted for closer monitoring, allowing more timely fungicide applications. In addition, plant species particularly susceptible to isolates of $P$. cryptogea or $P$. drechsleri could be maintained on separate flood or ebb-and-flow irrigation systems to slow the potential spread from crop to crop. In order to evaluate the host ranges of North Carolina isolates of $P$. cryptogea and $P$. drechsleri obtained from greenhouse-produced ornamentals, select isolates were tested for host specificity and variations in aggressiveness on eight floriculture crop species commonly produced in North Carolina greenhouses.

\section{Materials and Methods}

Host plants. Eight ornamental plant species commonly grown in North Carolina greenhouses were tested as hosts of isolates of $P$. cryptogea and $P$. drechsleri. Seed of dusty miller 'Maritima Silverdust', snapdragon (Antirrhinum majus) 'Snapshot Pink', annual stock (Matthiola incana) 'Hot Cakes Rose', and African marigold (Tagetes erecta) 'Marvel Gold', and rooted cuttings of osteospermum (Osteospermum sp.) 'Serenity Lemonade' were obtained from Ball Horticultural Company. Rooted cuttings of gerbera daisy 'Revolution Yellow' were provided by Van Wingerden International Inc.. Stock plants of verbena 'Lanai White' and rooted cuttings of fuchsia 'Winston Churchill' were produced by North Carolina Farms, Indian Trail. To produce rooted plugs of dusty miller, snapdragon, annual stock, and African marigold, seed were sown into 162-cell plug trays containing Fafard 2 peat-based potting mix (Conrad Fafard Inc.). Trays were maintained on a greenhouse bench with intermittent mist irrigation that cycled on for 1 min six times daily until a significant root system was established. To produce rooted plugs of verbena, terminal cuttings containing four to six leaves were taken from stock plants with sterile hand clippers. Cuttings were placed in 162-cell plug trays containing Fafard 2 peat-based potting mix and maintained under mist irrigation as described above for 10 to 14 days. Rooted plugs were transplanted into $460-\mathrm{cm}^{3}$ plastic pots containing Fafard $4 \mathrm{P}$ peat-based potting mix (Conrad Fafard Inc.). Once transplanted, plants were watered by drip irrigation for 1 min twice daily. Plants were fertilized with Peters 20-20-20 (N-P-K at 200 ppm; Scotts) weekly.

Phytophthora isolates and inoculum preparation. Three isolates of P. cryptogea (Pc597, Pc1105, and Pc1146) and three iso- 
lates of $P$. drechsleri (Pd103, Pd957, and Pdfdm5) were chosen from a collection of isolates obtained during two surveys of North Carolina greenhouse ornamentals (Table 1) $(12,25)$. The isolates were chosen based on host of origin. Inoculum was prepared by transferring five 4-mm-diameter agar disks from an actively growing culture into $125-\mathrm{ml}$ flasks of twice-autoclaved rice grains $(25 \mathrm{~g}$ of rice and $17 \mathrm{ml}$ of water) (11). Cultures were incubated 7 days at 20 to $25^{\circ} \mathrm{C}$. Flasks were shaken briefly each day to ensure uniform colonization of rice grains.

Host specificity and isolate aggressiveness. Greenhouse trials were conducted to test the host specificity and aggressiveness of the isolates of $P$. cryptogea and $P$. drechsleri. Plant species were divided into two groups arbitrarily, depending on the availability of planting material. Group 1 included annual stock, dusty miller, osteospermum, and snapdragon, and group 2 was composed of African marigold, fuchsia, gerbera daisy, and verbena. Plants were inoculated by placing one rice grain colonized by mycelia in each of three holes $1 \mathrm{~cm}$ deep in the potting mix of each pot. Noninoculated plants were included as controls. A factorial treatment design was utilized, and plants were arranged in a randomized complete block design with eight replications of each host-isolate treatment combination. The experiment was repeated twice for each group of plants. Plants were monitored for the development of foliar symptoms of Phytophthora root rot, including wilting, chlorosis, and necrosis. The plants were maintained in the greenhouse until no new plants in a test developed foliar symptoms for 10 days. Greenhouse average maximum and minimum temperatures for the tests were recorded (group 1 trial $1: 33 \pm 8^{\circ} \mathrm{C}$ day and $18 \pm 2^{\circ} \mathrm{C}$ night, group 1 trial 2: $34 \pm 5^{\circ} \mathrm{C}$ day and $20 \pm 3^{\circ} \mathrm{C}$ night, group 2 trial 1 : $35 \pm 7^{\circ} \mathrm{C}$ day and $19 \pm 4^{\circ} \mathrm{C}$ night, and group 2 trial $2: 38 \pm 7^{\circ} \mathrm{C}$ day and $23 \pm 3^{\circ} \mathrm{C}$ night).

Host specificity was evaluated by rating each plant as symptomatic $(=1)$ or nonsymptomatic $(=0)$ for plants developing foliar symptoms of root rot. Logistic regression was used to identify the factors (trial, block, host, isolate, and the host-isolate interaction) significantly associated with foliar symptom development. The model for each group of plants was fit with PROC LOGISTIC (SAS 9.2; SAS Institute), and Firth's bias correction was utilized to account for quasi-separation of the data (8). For both host groups, data were pooled for the two trials because trial was not a significant factor in the model $(P=0.05)$. The host-isolate interaction was significant (group 1: $P<0.0001$ and group 2: $P=0.0155$ ); therefore, the probability of an isolate causing foliar symptom development on each host plant compared with the noninoculated control was determined by the analysis of maximum likelihood estimates (1).

For isolates that caused foliar symptoms of root rot on a particular host, differences in isolate aggressiveness were evaluated by analyzing the number of days between inoculation and development of foliar symptoms of root rot. Data were analyzed for each plant group with PROC GLIMMIX (SAS 9.2; SAS Institute) and a Poisson distribution. Plants that did not develop foliar symptoms were regarded as missing data points. Host, isolate, and the interaction were treated as fixed effects, and trial and block were treated as random effects. Trial was not significant $(P=0.05)$ in the model; therefore, the data were pooled for the two trials for both groups. The host-isolate interaction was significant (groups 1 and 2: $P<0.0001)$; therefore, the least-squares means were calculated for the interactions and the simple effects were analyzed by host to determine significant isolate differences.
Isolation from nonsymptomatic plants. To determine whether inoculated plants that did not develop foliar symptoms of root rot were colonized by the Phytophthora isolate, the roots from up to four replicate plants per host-isolate combination were collected randomly from each trial, washed under running water to remove potting mix, and plated onto cornmeal agar (BD Diagnostics) amended with pimaricin, ampicillin, rifamycin, and pentachloronitrobenzene (16). In addition, the roots of one symptomatic plant per host-isolate combination were plated as a control for the isolation procedure. Plates were incubated at 20 to $25^{\circ} \mathrm{C}$ in the dark for up to 7 days and observed for growth of Phytophthora spp. Colonies were observed with a microscope to confirm that the morphology was consistent with Phytophthora and that the hyphal growth was emerging from the plant root.

\section{Results}

Host specificity. No isolate of $P$. cryptogea or $P$. drechsleri caused disease on all tested plant species, and no tested isolate of $P$. cryptogea or $P$. drechsleri caused disease on African marigold (Fig. 1) Overall, the $P$. cryptogea isolates exhibited more variability in host range than the $P$. drechsleri isolates (Fig. 1). P. cryptogea isolates Pc594 and Pc1105 had very similar host ranges (Table 2). Osteospermum, annual stock, fuchsia, and gerbera daisy plants inoculated with Pc594 and Pc1105 had a significantly greater probability (osteospermum: $P=0.0008$; annual stock: $P=0.0008$ and 0.0025 , respectively; fuchsia: $P=0.037$; gerbera daisy: $P=$ 0.0235 and 0.0044 , respectively) of developing foliar symptoms of Phytophthora root rot than the noninoculated control (Fig. 1). In addition to these hosts, Pc1105 caused significant $(P=0.0008)$ disease on snapdragon. Approximately $20 \%$ of snapdragon plants inoculated with Pc594 wilted; however, the plants did not have a greater probability $(P=0.05)$ of developing disease than the noninoculated plants. Similarly, $30 \%$ of dusty miller plants inoculated with Pc1105 wilted and developed crown rot but the probability was not significantly $(P=0.05)$ greater than the noninoculated control plants (Fig. 1). Pc1146 had a smaller host range than the other isolates of $P$. cryptogea (Table 2). Dusty miller, annual stock, and gerbera daisy plants inoculated with Pc1146 developed significant $(P=0.0044,0.0008$, and 0.0370 , respectively) foliar symptoms of Phytophthora root rot (Fig. 1). In addition, approximately $25 \%$ of snapdragon plants and $10 \%$ of verbena plants inoculated with Pc1146 wilted but the plants did not have a significantly greater probability $(P=0.05)$ of developing disease.

P. drechsleri isolates Pd957 and Pdfdm5 had very similar host ranges (Table 2). Both isolates caused significant $(P=0.0008)$ wilting of dusty miller, osteospermum, snapdragon, annual stock, and gerbera daisy (Fig. 1). In addition, Pd957 had a significantly greater probability $(P=0.0008)$ of causing foliar symptoms of Phytophthora root rot than the noninoculated control on fuchsia $(P$ $=0.037)$ and verbena $(P=0.0008)$. In contrast, only $25 \%$ of fuchsia plants and $10 \%$ of verbena plants inoculated with Pdfdm5 wilted, which was not significantly greater $(P=0.05)$ than the noninoculated fuchsia and verbena plants. In contrast with isolates Pd957 and Pdfdm5, P. drechsleri isolate Pd103 only caused disease on osteospermum plants (Table 2). Approximately 50\% of osteospermum plants inoculated with Pd103 wilted and developed crown rot, which was a significantly greater probability $(P=$ 0.0252) than the noninoculated control (Fig. 1).

Variations in isolate aggressiveness. The days to initial visible symptom development ranged from approximately 7 days on snap-

Table 1. North Carolina isolates of Phytophthora cryptogea and P. drechsleri used in host specificity and aggressiveness testing

\begin{tabular}{lccl}
\hline Isolate designation & Species & Year isolated & Host name \\
\hline Pd103 & P. drechsleri & 2007 & Gerbera jamesonii, Gerbera daisy \\
Pd957 & P. drechsleri & 2008 & Fuchsia $\times$ hybrida, Fuchsia \\
Pdfdm5 & P. drechsleri & 2001 & Senecio cineraria, Dusty miller \\
Pc597 & P. cryptogea & 2008 & G. jamesonii, Gerbera daisy \\
Pc1105 & P. cryptogea & 2008 & Verbena $\times$ hybrida, Verbena \\
Pc1146 & P. cryptogea & 2008 & Senecio cineraria, Dusty miller \\
\hline
\end{tabular}


dragon and annual stock to over 30 days on fuchsia (Fig. 2). On verbena, there were no statistical differences $(P=0.05)$ between isolates with wilting developing in 20 to 30 days after inoculation for all isolates. Isolate aggressiveness depended on host but, overall, $P$. drechsleri isolates Pd957 and Pdfdm5 were more aggressive than the $P$. cryptogea isolates (Fig. 2).

For the $P$. drechsleri isolates, there was very little variability in isolate aggressiveness, and there were no significant differences $(P$ $=0.05$ ) in the days to foliar symptom development between Pd957 and Pdfdm5 on osteospermum, snapdragon, fuchsia, or gerbera daisy (Fig. 2). On osteospermum, both isolates caused wilting and chlorosis to develop within 12 to 14 days, which was significantly faster than $P$. drechsleri isolate $\operatorname{Pd} 103(P=0.0001)$. Annual stock plants inoculated with Pd957 developed foliar symptoms significantly faster than plants inoculated with Pdfdm5 $(P=0.0001)$. In contrast, Pdfdm5 was significantly more aggressive than Pd957 on dusty miller $(P=0.0065)$.

The $P$. cryptogea isolates were more variable in aggressiveness than the isolates of $P$. drechsleri (Fig. 2). Isolate Pc1146 was more aggressive than Pc1105 on dusty miller $(P=0.0002)$ and Pc594
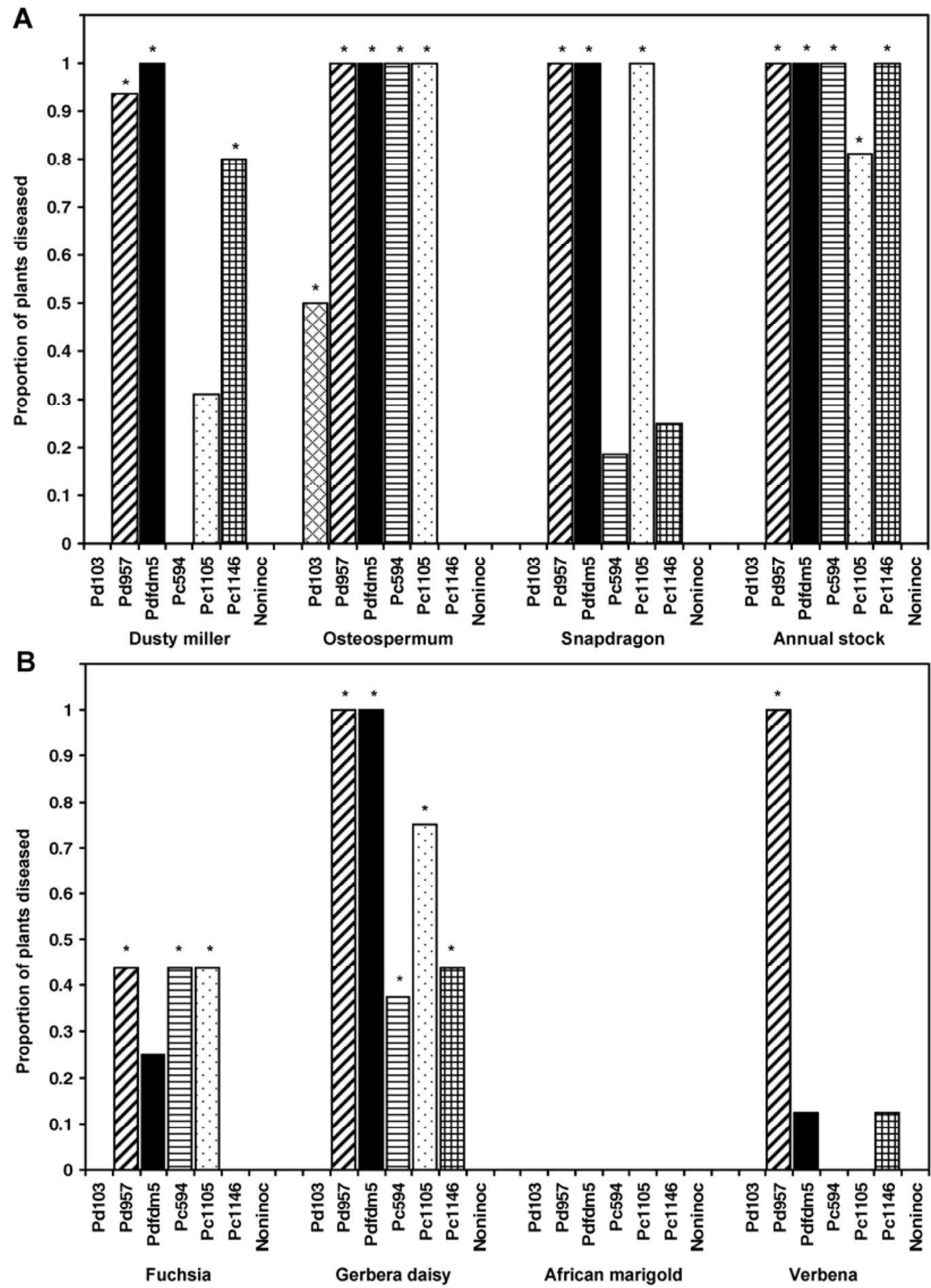

Fig. 1. Proportion of plants that developed foliar symptoms of Phytophthora root rot when inoculated with isolates of Phytophthora drechsleri (Pd103, Pd957, and Pdfdm5) and P. cryptogea (Pc594, Pc1105, and Pc1146). A, Dusty miller, osteospermum, snapdragon, and annual stock; B, fuchsia, gerbera daisy, African marigold, and verbena. Bars are means of data pooled across two trials with eight replications per trial. Bars marked with * indicate that plants inoculated with the corresponding isolate had a significantly greater probability $(P=0.05)$ of developing foliar symptoms of Phytophthora root rot than the noninoculated control (Noninoc) as determined by the analysis of maximum likelihood estimates from PROC LOGISTIC with Firth's bias correction (SAS 9.2; SAS Institute). 
and Pc1105 on annual stock $(P=0.0001)$, with plants inoculated with Pc1146 developing foliar symptoms of root rot within 14 days (Fig. 2). On osteospermum, Pc1105 was significantly $(P=0.0053)$ more aggressive than Pc594. Isolates of $P$. cryptogea exhibited the greatest variability in aggressiveness on snapdragon (Fig. 2). Snapdragon plants inoculated with Pc1105 developed foliar symptoms within 10 days, which was significantly faster than Pc594 $(P=$ $0.0001)$ and Pc1146 $(P=0.0187)$, and Pc1146 was significantly more aggressive than Pc594 $(P=0.0001)$, with symptoms developing in 14 and 20 days, respectively. Gerbera daisy plants inoculated with Pc1105 and Pc1146 developed foliar symptoms significantly faster than plants inoculated with Pc $594(P=0.0010$ and 0.0218 , respectively). There was no significant $(P=0.05)$ difference between $P$. cryptogea isolates on fuchsia, with foliar symptoms developing 30 to 35 days after inoculation (Fig. 2).

Root colonization of nonsymptomatic host plants. Upon visual inspection, root necrosis was evident in some inoculated plants that were not exhibiting foliar symptoms; however, in many inoculated plants, there was no root necrosis visible to the unaided eye. Overall, Phytophthora was isolated from 116 of 245 inoculated host plants not exhibiting foliar symptoms (Table 3). The only successful isolation from African marigold was a single plant inoculated with $P$. drechsleri isolate Pdfdm5. Isolate Pd103 was recovered from $50 \%$ of sampled osteospermum plants; however, there were no successful isolations of Pd103 from any other nonsymptomatic host plant species. Isolate Pd957 was recovered from all tested nonsymptomatic dusty miller and fuchsia plants (Table 3). Similarly, Pdfdm5 was isolated from $100 \%$ of sampled nonsymptomatic fuchsia plants and $63 \%$ of verbena plants. Isolate Pc594 of P. cryptogea was recovered from 38 to $100 \%$ of tested dusty miller, snapdragon, fuchsia, gerbera daisy, and verbena plants. Pc1105 was isolated from over 50\% of dusty miller, annual stock, fuchsia, gerbera daisy, and verbena plants not exhibiting foliar symptoms. Likewise, over half of tested dusty miller, osteospermum, snapdragon, fuchsia, gerbera daisy, and verbena plants were colonized by Pc1146 yet plants were nonsymptomatic (Table 3).

\section{Discussion}

Inoculation studies in eight ornamental host plants with three isolates of $P$. cryptogea and three isolates of $P$. drechsleri originally isolated from ornamental plant species grown in North Carolina greenhouse facilities identified differences in host ranges. The host ranges varied between isolates within both species. No isolate of $P$. cryptogea or $P$. drechsleri caused foliar symptoms of Phytophthora root rot on all host species, and no plant species was susceptible to all isolates of both species. In addition, variations in aggressiveness as determined by the days to foliar symptom development between isolates on a host plants species were evident.

Of the three isolates of $P$. cryptogea evaluated, no isolate had the same host range. Other reports indicate that ornamental isolates of $P$. cryptogea frequently have differing host ranges. Tompkins and Tucker (34) tested isolates of $P$. cryptogea from China-aster, annual stock, and gerbera daisy. The China-aster isolate had the largest host range and caused disease on wallflower, annual stock, gerbera daisy, Michaelmas daisy, hybrid cineraria, and a variety of vegetable plants. In contrast, the annual stock isolate only infected Chinaaster and gerbera daisy, and only annual stock developed disease when inoculated with the gerbera daisy isolate (34). Similarly,
Middleton et al. (24) evaluated nine isolates of P. cryptogea on eight ornamental host species, and six of the nine isolates had unique host ranges. Rattink (30) tested isolates of P. cryptogea from begonia and gerbera daisy and demonstrated that the begonia isolate only caused disease on begonia and sinningia but the gerbera daisy isolate caused disease on begonia, gerbera daisy, and peperomia. Likewise, Kröber (19) determined that isolates from Elatior begonia could cause disease on Elatior begonia and gerbera daisy but that isolates from China-aster and gerbera daisy were not pathogenic to Elatior begonia.

In the present study, annual stock and gerbera daisy were the only host species on which all three isolates of $P$. cryptogea caused significant disease. These plant species are well-established hosts of $P$. cryptogea and frequently were infected in other ornamental host range investigations $(9,13,15,18,26,34)$. Tompkins and Tucker (34) reported that an isolate of $P$. cryptogea from annual stock was pathogenic to gerbera daisy and that an isolate of $P$. cryptogea from gerbera daisy was pathogenic to annual stock. Similarly, Middleton et al. (24) found that all tested isolates of P. cryptogea caused root rot on annual stock and gerbera daisy regardless of the host of origin.

During the 1970s, P. cryptogea was first identified as a serious pathogen of osteospermum in California, where it was causing a destructive root rot in outdoor ornamental plantings (10). Recently, P. cryptogea was reported causing stem rot on osteospermum in commercial nurseries in South Africa (23). In the present study, two isolates of $P$. cryptogea caused foliar symptoms of root rot on all inoculated osteospermum plants in approximately 14 to 18 days in the greenhouse. This indicates that $P$. cryptogea still has the potential to be a serious pathogen in this host, even though there are few published reports of $P$. cryptogea attacking osteospermum. It was expected that all isolates of $P$. cryptogea would cause foliar symptoms of root rot on osteospermum because it is in the same plant family (Asteraceae) as gerbera daisy, which was a host for all $P$. cryptogea isolates. Likewise, it was anticipated that all isolates of $P$. drechsleri would incite root rot on gerbera daisy because all isolates caused disease on osteospermum. However, in both instances, only two isolates of $P$. cryptogea and two isolates of $P$. drechsleri caused foliar symptoms of root rot on osteospermum and gerbera daisy, respectively. This suggests that host range may be more specific than the plant family level. Stirling and Irwin (31) reported that plant family was not a predictor of host range for isolates of $P$. cryptogea. An isolate from guar bean did not cause disease on cowpea, mung bean, common bean, or chickpea, which are in the Fabaceae family with guar bean, whereas sunflower and safflower, which are in the Asteraceae family, were highly susceptible to the guar bean isolate.

To our knowledge, this is the first work investigating the host range of ornamental isolates of $P$. drechsleri obtained from greenhouses. The isolates of $P$. drechsleri evaluated in this study varied greatly in their host ranges, with isolate Pd103 only causing symptoms on osteospermum whereas isolates Pd957 and Pdfdm5 were relatively nonspecific and caused disease on the majority of tested host species. Pratt et al. (29) compared the pathogenicity of 35 isolates of $P$. drechsleri obtained from native forests, safflower, and citrus orchard soil on safflower, sunflower, and watermelon. All inoculated safflower plants developed severe disease symptoms regardless of the isolate origin. However, no sunflower or water-

Table 2. Summary of host ranges for isolates of Phytophthora drechsleri and P. cryptogea determined from hosts that had a significantly greater probability of developing disease $(+)$ than the noninoculated control

\begin{tabular}{|c|c|c|c|c|c|c|c|c|}
\hline \multirow[b]{2}{*}{ Isolate } & \multicolumn{8}{|c|}{ Host } \\
\hline & Dusty miller & Osteospermum & Snapdragon & Annual stock & Fuchsia & Gerbera daisy & African marigold & Verbena \\
\hline Pd103 & - & + & - & - & - & - & - & - \\
\hline Pd957 & + & + & + & + & + & + & - & + \\
\hline Pdfdm5 & + & + & + & + & - & + & - & - \\
\hline Pc594 & - & + & - & + & + & + & - & - \\
\hline Pc1105 & - & + & + & + & + & + & - & - \\
\hline Pc1146 & + & - & - & + & - & + & - & - \\
\hline
\end{tabular}


melon plants developed root rot. Most host range investigations with $P$. drechsleri have involved evaluating a single isolate of $P$. drechsleri on a range of host plants with no comparison of isolates from different hosts. However, by comparing across studies, it is evident that, similar to the host range variation observed in our ornamental isolates, $P$. drechsleri isolates collected from fruit and other crops plants appear to range from nonspecific to highly specific. Alavi (2) reported that an isolate of $P$. drechsleri obtained from cantaloupe was nonspecific and caused root rot on all tested plant species, including soybean, pigweed, lambsquarter, puslane, and black nightshade. Likewise, an isolate from watermelon fruit evaluated by Katsura (17) was nonspecific and infected fruit of cucumber, eggplant, plum, carrot roots, and kidney bean pods. In contrast, an isolate of $P$. drechsleri from an unknown host origin was evaluated on 15 weed and 17 cultivated plant species (4). Of the 32 tested plant species, only alfalfa, safflower, and skeleton weed developed significant disease.

The reported host range of $P$. drechsleri in greenhouse-produced ornamentals is limited to approximately 25 species (7). Pathogenicity of isolate Pd957, originally collected from fuchsia (25),
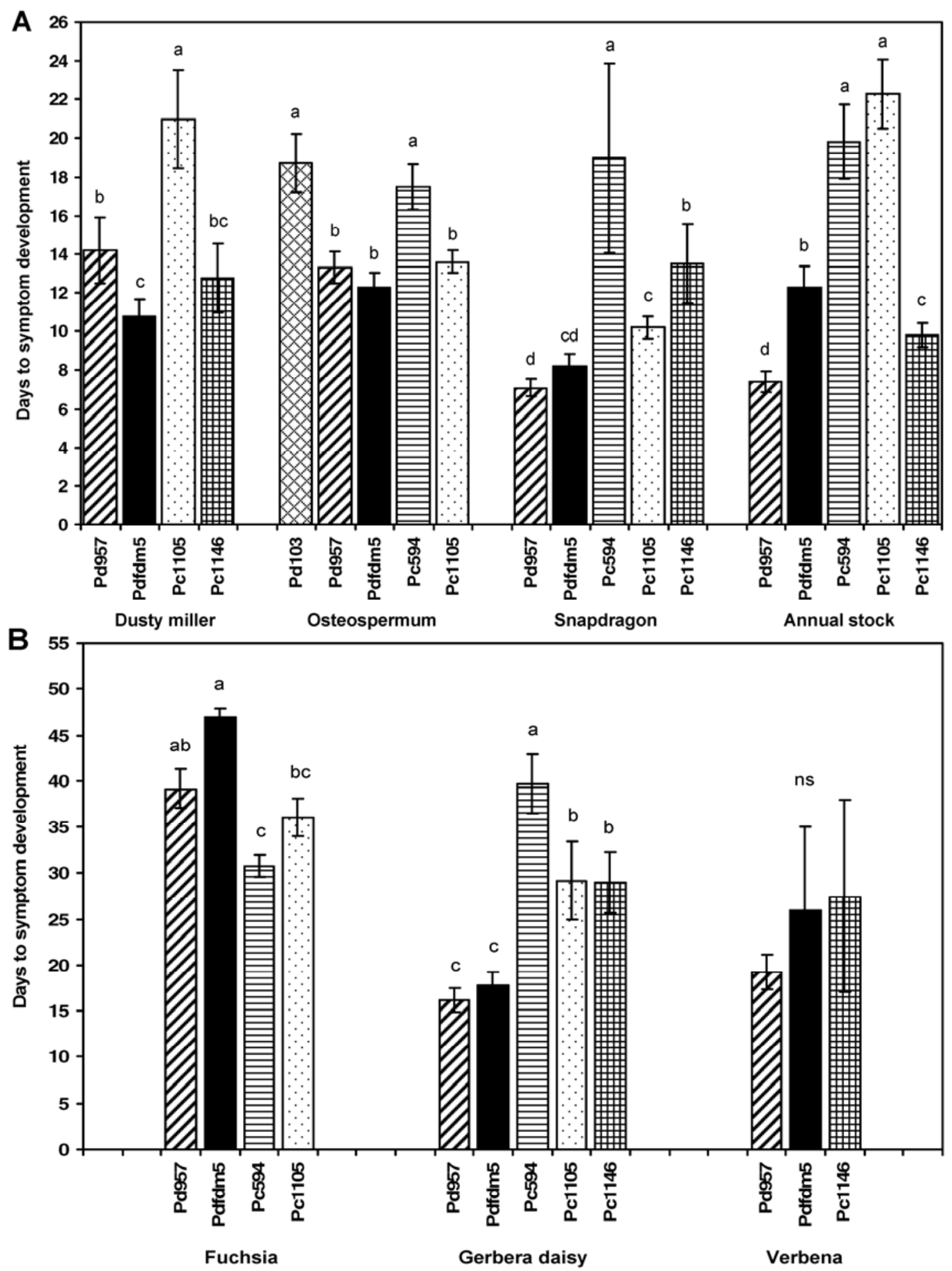

Fig. 2. Days to development of foliar symptoms for plants inoculated with Phytophthora drechsleri isolates Pd103, Pd957, and Pdfdm5 and P. cryptogea isolates Pc594, Pc1105, and Pc1146. A, Dusty miller, osteospermum, snapdragon, and annual stock; B, fuchsia, gerbera daisy, African marigold, and verbena. Isolates within each host shown with a different letter are significantly different (A, host-isolate $P<0.0001 ; \mathrm{B}$, host-isolate $P=0.002$ ) according to an analysis of simple effect comparisons of the interaction least square means using pairwise $t$ tests. Each bar is the mean of data pooled from two independent trials with eight replications per trial. Error bars represent the standard error. 
was confirmed because the isolate caused Phytophthora root rot on fuchsia during the greenhouse studies. Symptoms progressed from stunting and nutrient stress to defoliation starting with the lower leaves and eventual plant death. The present greenhouse inoculation studies also expand the potential ornamental host range of $P$. drechsleri considerably. Osteospermum, snapdragon, and annual stock have not been reported as hosts of $P$. drechsleri. In this study, osteospermum was the only host on which all three isolates of $P$. drechsleri caused disease, with foliar symptoms of Phytophthora root rot developing within 12 to 20 days. Similarly, isolates Pd957 and Pdfdm5 caused disease on all inoculated snapdragon and annual stock plants within 7 to 14 days. These results suggest that $P$. drechsleri has the potential to be a serious pathogen of osteospermum, snapdragon, and annual stock if introduced to a greenhouse producing these plants. Verbena also has not been reported as a host of $P$. drechsleri. However, only isolate Pd957 caused significant Phytophthora root rot on verbena; therefore, verbena may not be as susceptible of an ornamental species.

In several cases, isolates of both Phytophthora spp. caused disease on a small percentage of host plants but the probability of disease developing in a host species was not statistically significant. The host range of isolates potentially could fluctuate depending on the state of the host plant. Under conditions where the plant is stressed, the isolate could be pathogenic to the particular plant but, when the plant is not stressed, the isolate is not a serious pathogen. Thinggaard and Anderson (32) found that increasing the watering frequency in an ebb and flow system increased gerbera daisy mortality from P. cryptogea from 13.5 to $73.6 \%$. In chrysanthemum, salinity stress within $24 \mathrm{~h}$ of inoculation and heat stress induced by exposing pots to direct sunlight increased susceptibility to $P$. cryptogea $(21,22)$. In safflower screening studies, Zimmer and Urie (36) reported that increased irrigation frequency and intensity or moisture stress prior to irrigation increased safflower mortality in cultivars normally resistant to $P$. drechsleri.

Two isolates, Pd103 and Pc1105, did not cause disease on their hosts of origin, gerbera daisy and verbena, respectively. For these two isolates, the cultivar of each host used in this study was not the cultivar from which the isolate was collected originally; therefore, the lack of disease development could be a result of differences in cultivar susceptibility within plant species. While evaluating gerbera daisy cultivars for resistance to Phytophthora root rot caused by $P$. cryptogea, Yue et al. (35) demonstrated that pathogenicity of the six isolates used in the screening depended greatly on the cultivar being tested. Similarly, 15 cultivars of guar bean inoculated with an isolate of $P$. cryptogea exhibited a range of susceptibility from approximately 25 to $100 \%$ mortality (31). Orlikowski and Ptaszek (27) reported significant differences in susceptibility to cultivars of houseleeks when inoculated with an isolate of $P$. cryptogea. Cultivar-isolate interactions have been reported in screening of safflower cultivars for resistance to P. drechsleri, leading several researchers to suggest the development of races within this species $(33,36)$. Overcoming the possible effect of cultivar in future host range screenings of ornamental species for susceptibility to Phytophthora spp. likely will be difficult because of the large number of commercially available cultivars and the changing nature of the ornamental industry, where new cultivars are introduced constantly and old cultivars become unavailable.

The majority of host range studies have evaluated only the development of disease (i.e., yes or no), with no considerations for differences in isolate aggressiveness on a particular host. Although isolates of $P$. cryptogea and $P$. drechsleri had overlapping host ranges, differences in isolate aggressiveness were evident when evaluated as a function of days to disease development. On the majority of host plants, the isolates of $P$. drechsleri were more aggressive than the isolates of $P$. cryptogea, the exception being on fuchsia. In contrast, on kiwifruit vines, Conn et al. (3) found that $P$. cryptogea isolates were consistently more aggressive than $P$. drechsleri isolates. Tompkins and Tucker (34) found that the average incubation period for isolates of $P$. cryptogea was 10 days for China aster, 24 days for annual stock, and 45 days for gerbera daisy. The days to disease development for most of our isolates of $P$. cryptogea on annual stock and gerbera daisy compared very closely to Tompkins and Tucker (34). Most annual stock plants wilted in approximately 18 to 24 days, whereas gerbera daisy plants developed disease more slowly, with symptoms appearing in 30 to 40 days. Within a species, no one isolate was consistently more aggressive and aggressiveness always depended on the host. Orlikowski and Ptaszek (27) compared aggressiveness by lesion development on European columbine and houseleek inoculated with isolates of P. cryptogea from six ornamental species. After 5 days, variations in isolate aggressiveness were evident on both plants, and the isolate aggressiveness varied by plant. On European columbine, lesions were largest on plants inoculated with the isolates from gerbera daisy, European columbine, and White Mountain saxifrage. In contrast, $P$. cryptogea isolates from gerbera daisy, mossy saxifrage, and houseleek were the most aggressive on houseleek (27). Variations in aggressiveness of isolates of $P$. cryptogea have been reported in other crops. Larsson and Gerhardson (20) tested an isolate of $P$. cryptogea obtained from spinach on spinach, sugarbeet, wheat, cucumber, oat, pea, and rape. The isolate caused disease on all tested hosts. However, the isolate was highly aggressive on spinach and sugarbeet; moderately aggressive on wheat, cucumber, and pea; and slightly aggressive on oat and rape. The growth rate of mycelium in tomato plants varied greatly between isolates of $P$. cryptogea from Edelweiss, gerbera daisy, melon, cucumber, aster, sugar beet, tomato, pepper, and strawberry (14). Isolates from tomato, pepper, and strawberry had the fastest growth on tomato, and isolates from Edelweiss, gerbera daisy, and melon had the slowest growth rate.

African marigold was the only host species that did not develop foliar symptoms of Phytophthora root rot. Although P. cryptogea has been reported as a causal agent of root rot in African marigold in the early literature (28), no isolate of P. cryptogea was found to infect the roots of African marigold based on the isolations from nonsymptomatic plants. African marigold has not been reported as a host of $P$. drechsleri and, like the $P$. cryptogea isolates, was not isolated readily from nonsymptomatic hosts. This suggests that African marigold may not be a common host of these Phytophthora spp. and should be investigated further for disease resistance. In contrast to African marigold, the roots of many nonsymptomatic test plants were found to be infected with Phy-

Table 3. Isolation of Phytophthora drechsleri and P. cryptogea from the roots of host plants not exhibiting foliar symptoms of Phytophthora root rot at the conclusion of the greenhouse studies

\begin{tabular}{lcccccccc}
\hline & \multicolumn{7}{c}{ Isolation from host plants not exhibiting foliar symptoms (success/total) } \\
\cline { 2 - 8 } Isolate & Dusty miller & Osteospermum & Snapdragon & Annual stock & Fuchsia & Gerbera daisy & African marigold & Verbena \\
\hline Pd103 & $0 / 8$ & $4 / 8$ & $0 / 8$ & $0 / 8$ & $0 / 8$ & $0 / 8$ & $0 / 8$ & $0 / 8$ \\
Pd957 & $1 / 1$ & - & - & - & $8 / 8$ & - & - & $0 / 8$ \\
Pdfdm5 & - & - & - & - & $8 / 8$ & $7 / 8$ & $5 / 8$ \\
Pc594 & $6 / 8$ & - & - & - & $3 / 3$ & $6 / 8$ & $2 / 8$ & $0 / 8$ \\
Pc1105 & $6 / 8$ & - & $7 / 8$ & - & $4 / 8$ & $5 / 8$ & $0 / 8$ & $0 / 8$ \\
Pc1146 & $4 / 5$ & $8 / 8$ & &
\end{tabular}

a Number of successful isolations/number of total isolations. 
tophthora. In the floriculture industry, it is common for plant material to move around the United States and even from off-shore into the United States (5). Nonsymptomatic plant material infected with one of these Phytophthora spp. potentially could be shipped between growers or from production growers to retailers, thereby introducing Phytophthora spp. to new greenhouses or to landscapes. In the nursery industry, Phytophthora spp. are known to be moved between locations on nonsymptomatic plant material, the most notable recent example being $P$. ramorum (5). It seems likely that this also is occurring in the greenhouse industry, based on the number of nonsymptomatic plants infected with either $P$. cryptogea or $P$. drechsleri, and should be taken into consideration in the management of these pathogens.

Overall, these studies indicate that isolates of P. cryptogea and $P$. drechsleri have varying host ranges. Osteospermum, annual stock, and gerbera daisy were identified as being more likely to be attacked by these species than other plant species. This increased likelihood should be considered by growers when developing a disease management program for these plant species. Growers utilizing ebb-and-flow or flood-floor irrigation should consider separating these crops to minimize the potential for crop-to-crop spread. Scouting for root rot symptoms could target these plants to more quickly identify the onset of Phytophthora root rot epidemics. The large number of infected nonsymptomatic plants found is alarming and suggests that movement of such plants likely has a large role in the movement of these Phytophthora spp. throughout the industry and may result in these pathogens being introduced into the environment.

\section{Acknowledgments}

Funding for this research comes, in part, from the Fred C. Gloeckner Foundation, Harrison, NY; the United States Department of Agriculture-Agricultural Research Service Floriculture and Nursery Crops Research Initiative; and the North Carolina Agricultural Research Service, Raleigh. We thank J. Dole and K. C. Parker for technical assistance, and C. Arellano and B. Shew for their invaluable help in the statistical analysis of this research.

\section{Literature Cited}

1. Agresti, A. 1996. An Introduction of Categorical Data Analysis. John Wiley \& Sons, Inc., New York.

2. Alavi, A. 1990. The role of alternative hosts in overwintering of Phytophthora drechsleri. Appl. Entomol. Phytopathol. 57:21-22.

3. Conn, K. E., Gubler, W. D., Mircetich, S. M., and Hasey, J. K. 1991. Pathogenicity and relative virulence of 9 Phytophthora spp. from kiwifruit. Phytopathology 81:974-979.

4. Cother, E. J. 1975. Phytophthora drechsleri: Pathogenicity testing and determination of effective host range. Aust. J. Bot. 23:87-94.

5. Daughtrey, M. L., and Benson, D. M. 2005. Principles of plant health management for ornamental plants. Annu. Rev. Phytopathol. 43:141-169.

6. Farr, D. F., and Rossman, A. Y. Phytophthora cryptogea. Fungal Databases, Systematic Botany and Mycology Laboratory, ARS, USDA. Online publication. Accessed 15 January 2012. http://nt.ars-grin.gov/fungal databases/

7. Farr, D. F., and Rossman, A. Y. Phytophthora drechsleri. Fungal Databases, Systematic Botany and Mycology Laboratory, ARS, USDA. Online publication. Accessed 15 January 2012. http://nt.ars-grin.gov/fungal databases/

8. Firth, D. 1993. Bias reduction of maximum likelihood estimates. Biometrika 80:27-38.

9. French, A. M. 1989. California Plant Disease Host Index. California Department of Food and Agriculture, Sacramento.

10. Gill, H. S., Zentmyer, G. A., Ribeiro, O. K., and Klure, L. J. 1976. A Phytophthora disease of African daisies (Osteospermum spp.) in California. Plant Dis. Rep. 60:647.
11. Holmes, K. A., and Benson, D. M. 1994. Evaluation of Phytophthora parasitica var. nicotianae for biocontrol of Phytophthora parasitica on Catharanthus roseus. Plant Dis. 78:193-199.

12. Hwang, J., and Benson, D. M. 2005. Identification, mefenoxam sensitivity, and compatibility type of Phytophthora spp. attacking floriculture crops in North Carolina. Plant Dis. 89:185-190.

13. HyeongJin, J., WanGyu, K., SangYub, L., and WeonDae, C. 1996. Phytophthora cryptogea causing the foot rot of Gerbera jamesonii in Korea. Korean J. Plant Pathol. 12:374-376.

14. Ilieva, E., Jamart, G., and Kamoen, O. 1992. Characterization of some isolates of Phytophthora cryptogea. Parasitica 48:113.

15. Kaewruang, W., Sivasithamparam, K., and Hardy, G. E. 1988. Phytophthora cryptogea, an additional pathogen of gerbera in Western Australia. Australas. Plant Pathol. 17:67-68.

16. Kanwischer, M. E., and Mitchell, D. J. 1978. The influence of a fungicide on the epidemiology of black shank of tobacco. Phytopathology 68:17601765 .

17. Katsura, K. 1958. A Phytophthora rot of watermelon caused by $P$ drechsleri. Sci. Rep. Faculty Agric. Saikyo Univ. 10:77-85.

18. Kimishima, E., and Goto, M. 1992. Foot rot of gerbera caused by Phytophthora cryptogea Pethyb. \& Laff. in Japan. Ann. Phytopathol. Soc. Jpn. 58:87-90.

19. Krober, H. 1981. Comparative studies of isolates different from the common type of Phytophthora cryptogea and of Phytophthora drechsleri. J. Phytopathol. 102:219-231.

20. Larsson, M., and Gerhardson, B. 1990. Isolates of Phytophthora cryptogea pathogenic to wheat and some other crop plants. J. Phytopathol. 129:303315.

21. MacDonald, J.D. 1984. Salinity effects on the susceptibility of chrysanthemum roots to Phytophthora cryptogea. Phytopathology 74:621-624.

22. MacDonald, J. D. 1991. Heat stress enhances Phytophthora root rot severity in container-grown chrysanthemums. J. Am. Soc. Hortic. Sci. 116:36-41.

23. McLeod, A., and Coertze, S. 2007. First report of Phytophthora cryptogea on Osteospermum spp. in South Africa. Plant Dis. 91:322-322.

24. Middleton, J. T., Tucker, G. M., and Tompkins, C. M. 1944. A disease of gloxinia caused by Phytophthora cryptogea. J. Agric. Res. 68:0405-0413.

25. Olson, H. A., and Benson, D. M. 2011. Characterization of Phytophthora spp. on floriculture crops in North Carolina. Plant Dis. 95:1013-1020.

26. Orlikowski, L. 1976. The pathogens of diseases of Gerbera jamesonii Bolus in some glasshouses in Poland./Przyczyny zamierania gerbery (Gerbera jamesonii Bolus) w niektorych gospodarstwach ogrodniczych w Polsce. Pr. Inst. Sadow. Skierniewicach 2:197-201.

27. Orlikowski, L., and Ptaszek, M. 2007. Phytophthora spp. in Polish ornamental nurseries. 1. Perennial plants, new hosts of P. cryptogea. J. Plant Prot. Res. 47:401-408.

28. Pirone, P. P. 1937. A new disease of marigolds. Florist and Nursery Exch. 88:52.

29. Pratt, B. H., Heather, W. A., and Shepherd, C. J. 1974. Pathogenicity to three agricultural plant species of Phytophthora drechsleri isolates from Australian forest communities. Aust. J. Bot. 22:9-12.

30. Rattink, H. 1980. Characteristics and pathogenicity of six Phytophthora isolates from pot plants. Neth. J. Plant Pathol. 87:83-90.

31. Stirling, A. M., and Irwin, J. A. G. 1986. Etiology of a newly described root rot of guar (Cyamopsis tetragonoloba) in Australia caused by Phytophthora cryptogea. Plant Pathol. 35:527-534.

32. Thinggaard, K., and Andersen, H. 1995. Influence of watering frequency and electrical conductivity of the nutrient solution on Phytophthora root rot in pot plants of gerbera. Plant Dis. 79:259-263.

33. Thomas, C.A., and Klisiewicz, J.M. 1963. Selective pathogenesis within Phytophthora drechsleri. Phytopathology 53:368.

34. Tompkins, C. M., and Tucker, C. M. 1937. Foot rot of China-aster, annual stock, and Transvaal daisy caused by Phytophthora cryptogea. J. Agric. Res. 55:563.

35. Yue, L., YunLong, L., Fan, L., XiaoYan, T., JingLan, C., and HaiRu, C. 2008. Identification of the disease resistance of Gerbera jamesonii cultivars to root rot and pathogenicity differentiation of Phytophthora cryptogea. J. Yunnan Agric. Univ. 23:33-35.

36. Zimmer, D. E., and Urie, A. L. 1967. Influence of irrigation and soil infestation with strains of Phytophthora drechsleri on root rot resistance of safflower. Phytopathology 57:1056-1059. 